\title{
NOTES RELATING TO THE FLORA OF BHUTAN: XXXIV. CONVOLVULACEAE
}

\author{
R. R. MILL*
}

\begin{abstract}
The typification of Rivea ornata (Roxb.) Choisy (Convolvulaceae), based on Lettsomia ornata Roxb., is discussed. $R$. ornata is shown to have been frequently (though not consistently) misapplied to a taxon from S India and Sri Lanka which has also been called Convolvulus candicans Roth ex Roem. \& Schult., nom. illegit.; it is here newly described as $R$. wightiana R.R. Mill. Lettsomia ornata was based on a specimen of a plant introduced to Calcutta Botanic Garden from Uttar Pradesh. This is synonymous with Rivea ornata var. griffithii C.B. Clarke, not Clarke's 'typical variety' which Prain formally named var. typica. Lectotypifications are proposed for two species names in Argyreia Lour. Calystegia hederacea Wall., Convolvulus arvensis L. and Dichondra repens J.R. \& G. Forst. are recorded from Bhutan for the first time.
\end{abstract}

Keywords. Arglreia, Calystegia, Convolvulus, Dichondra, lectotypifications, new records. new species, Rivea.

\section{TAXONOMY OF RIVEA ORNATA (ROXB.) CHOISY}

\section{Introduction}

For many years it has been generally accepted that there are two species of Rivea Choisy in the Indian subcontinent: $R$. hypocrateriformis (Desr. ex Lam.) Choisy, and R. ornata ( Roxb.) Choisy. R. hypocrateriformis, the type species of the genus ( Manitz, 1976), poses no taxonomic problems. This paper deals with $R$. ornata and other names synonymized with it by various authors.

Two taxa have been confused within $R$. ornata since its basionym, Lettsomia ornata Roxb., was transferred to Rivea by Choisy (1833). One of these (which includes the type of the basionym) is an erect shrub, hardly ever developing twining habit. This occurs along the sub-Himalayan tract as far east as Myanmar (Burma) and possibly Laos and Thailand. The other taxon, from southern India and Sri Lanka, is a vigorous climber. Other differences exist and the taxa are better regarded as distinct species. The name $R$. ornata has often, though not consistently, been incorrectly applied and stabilization of its application is desirable. A summary of the current nomenclature and typification of taxa mentioned in this paper is given below, with examples of the differing usages of each name where applicable.

Rivea ornata (Roxb.) Choisy, Convolv. Or. 27, t. 3 (1833), sensu lato: Don (1838: 254); Choisy in A.DC. (1845, 9: 326); Voigt (1845: 351 ); Drury (1866: 295); Woodrow (1898: 170); Haines (1910: 462); Osmaston (1927: 376); Vickery in Hara et al. (1982: 108); Naithani (1985: 448); Haridasan \& Rao (1987: 645).

* Royal Botanic Garden Edinburgh, 20A Inverleith Row. Edinburgh EH3 5LR, UK. 
Basionym: Lettsomia ornata Roxb., Hort. Bengal 13 (1814) nom. nud.; Roxb., Fl. Ind. ed. Carey \& Wall. 2: 86 (1824) \& ed. Carey 1: 496 (1832). Origin: [India, Uttar Pradesh], 'A native of the interior parts of India; from Cawnpore Colonel Hardwick sent the plants to the Botanic Garden at Calcutta ...'. Currently accepted nomenclatural type: a specimen made from a plant cultivated at Calcutta Botanic Garden from the above-cited living material, numbered Wallich 1369/2 (K-W, seen, labelled 'H.B.C. Roxb.'; G-DC, microfiche seen, similarly labelled). - See below under notes on the typification of L. ornata (pp. 231-232); Austin (1980) incorrectly designated the G-DC specimen as holotype.

Syn.: [Ipomoea ornata Roxb., Ic. Pl. Ined. no. 1535, ined. (Drawing made c.1803-4, based on material conspecific with Hardwicke's plant from N India.) - Unpublished combination, never later validated.]

Argyreia ornata (Roxb.) Sweet, Hort. Brit. 289 (1827); Choisy (1833) as 'A. ornata Sweet' (see below); Stewart \& Brandis (1874: 343) as 'A. ornata Sweet'; Brandis (1906: 484) in syn. of $R$. roxburghii. Type: same as Lettsomia ornata Roxb.

Convolvulus ornatus (Roxb.) Wall., Numer. List 37, no. 1369 (1829). Type: same as Lettsomia ornata Roxb. Other material cited (not type material): Napalia, 1821, Wallich 1369/1 (K-W), from 'Hetounra' [Hataura, near Kathmandu: $27^{\circ} 22^{\prime} \mathrm{N} 85^{\circ} 8^{\prime} \mathrm{E}$ ].

Rivea laotica sensu Raizada (1976: 166); Babu (1977: 328); Deva \& Jain (1979: 269). ? etiam Ooststr. in Blumea 8: 525 (1957).

Incorrect citations:

'Argyreia ornata Sweet h. suburb. 2 ed. p. 289': Choisy in Mem. Soc. Phys. Genève 6: 409 (1833). [Correctly A. ornata (Roxb.) Sweet, Hort. Brit. 289 (1827); there was no 'second edition' of Hortus suburbanus londinensis (Sweet, 1818), and the name did not appear either.]

'Rivea ornata Choisy, Mem. Soc. Phys. Genève 6: 409 (1833)'. [At present incorrect; becomes correct if its basionym, L. ornata Roxb., is excluded and the name conserved with a new type under Art. 14.1 to preserve historic usage.]

Excluded synonym: Convolvulus tarita Buch.-Ham., Cat. Dried Pls. 64, no. $515(1830)$ \& in Wall., Numer. List 67, no. 2253 (1830) nom. nud. [=R. hypocrateriformis (Desr. ex Lam.) Choisy]. Original material: Monghir, 10 ix 1811, F. Buchanan-Hamilton 515 (E; duplicate G-DC, same locality, date and handwriting on label, without indication of collector).

Rivea ornata (Roxb.) Choisy var. griffithii C.B. Clarke in Hook.f., Fl. Brit. India 4: 183 (1883): Prain (1894: 88-89; 1896: 537); Haines (1922: 585); Gupta (1928: 342); Kanjilal et al. (1939: 340); Deva \& Jain (1979: 269-272). Syntypes: 'BENGAL, Griffith, Falconer. - Possibly a cultivated form. One of Griffith's examples is from the Calcutta Botanic Garden, the other from Sikkim; Falconer's example is without locality'. Lectotype (designated here): unlocalized specimen leg. Falconer s.n. (K), probably collected in the Siwaliks (fide Prain, 1894: 88).

Rivea ornata auct. [non (Roxb.) Choisy based on Lettsomia ornata Roxb.]: Wight (1848: vol. 4, p. 12, t. 1356); Watt (1892: 558); Trimen (1895: 205-6); Cooke (1908: 254); Rao (1914: 275); Gamble (1922: 904); Austin in Dassanayake (1980, 1: 358-359, with typification 'holotype Wallich 1369, G-DC'); Henry et al. (1987: 111); Singh (1988: 452). [Austin (1980 loc. cit.) considered that the duplicate of Wallich 1369 in G-DC was the holotype; this assumption presumably arose from his citation of the name as $R$. ornata Choisy (rather than $R$. ornata (Roxb.) Choisy), which led him to suppose that the holotype must be in G-DC. In addition. examples of both Wallich 1369/1 and Wallich $1369 / 2$ exist in G-DC; hence the H.B.C. specimen (1369/2) should have been specified as type.]

Rivea ornata Choisy var. typica Prain (as 'typica Clarke') in J. Asiat. Soc. Bengal, Pt. 2, Nat. Hist. 63: 88 (1894). Type not specified but the basionym of $R$. ornata (Roxb.) Choisy was explicitly excluded by Prain, along with synonyms based on it. 
Syn.: Convolvulus candicans Roth ex Roem. \& Schult., Syst. Veg. 4: 273 \& 790 (1819) nom. illegit. non C. candicans Willd. ex Roem. \& Schult., op. cit. 302 (1819); Roth, Nov. Pl. Sp. 106 (1821). For type see below.

Lettsomia ornata sensu Wall. in Roxb. (ed. Carey \& Wall. 2: 86 fn., 1824, non Roxb. loc. cit. 1824).

Rivea roxburghii Prain in J. Asiat. Soc. Bengal, Pt. 2, Nat. Hist. 63: 89 (1894) nom. inval.: Prain ex Brandis, Indian Trees 484 (1906); Kanjilal et al. (1939: 340) in syn. of R. ornata var. griffithii: Deva \& Jain (1979: 269) in syn. of $R$. ornata var. griffithii. Type: not stated, but an avowed nomen novum for Lettsomia ornata Roxb. non Rivea ornata sensu Choisy and thus to be typified by the type of L. ornata, i.e. Roxburgh in herb. Wallich 1369/2.

Convolvulus candicans Roth ex Roem. \& Schult., Syst. Veg. 4: 273 \& 790 (1819) nom. illegit. Type: 'India orientali', B. Heyne (?K, not located; a $\mathrm{K}$ sheet ex hb. Rottler bearing several separate specimens may include the type as well as type material of $C$. candicans Willd. ex Roem. \& Schult.; the specimens were determined by Clarke as $R$. hypocrateriformis). - Non C. candicans Sol. ex Sims in Bot. Mag. t. 1603 (1813; type, from material cult. K in 1776 probably originating from America; =Ipomoea tiliacea (Willd.) Choisy); nec C. candicans Willd. ex Roem. \& Schult., op. cit. 302 (1819 nom. illegit. \& Ipomoea candicans Rottler mss. nom. inval.: type, Tranquebar, Klein, B-Willd. 3692, microfiche seen, and LINN-Smith 307.16, microfiche seen; renamed Lettsomia uniflora Roxb., Fl. Ind. 2: 85 (1824), =R. hypocrateriformis.)

\section{Typification of Lettsomia ornata Roxb.}

Roxburgh (1814) indicated that he had received material of Lettsomia ornata from Hardwicke in 1802, from 'Hindoostan'. Thomas Hardwicke (1756-1835) was Captain of the 1st Company of the 3rd Battalion of the military service of the East India Company at Cawnpore from 1797-1803 (Dawson, 1946). These dates agree with the information in Roxburgh $(1814,1824)$ concerning the origin of the plant. Hardwicke presumably collected the plant in the vicinity of Cawnpore from where we know he sent it to Roxburgh for cultivation. Prain (1894: 88) stated that Hardwicke 'did not, so far as can be ascertained, collect in Southern India', a crucial fact in relation to the subsequent confusion that has arisen over the application of Roxburgh's name to plants from S India. No specimen of $L$. ornata has yet been traced that bears Roxburgh's own handwriting. Those in K-W and G-DC bear Wallich's labels; that in K-W is undated, that in G-DC is dated 1830 but not by Wallich. Thus, I refrain from designating either of them as lectotype of $L$. ornata since it is possible that a specimen from the Calcutta Botanic Garden collection of L. ornata may exist elsewhere that can be more directly attributed to Roxburgh. However, Wallich 1369 (in the broad sense) has historically been considered to be the type of $L$. ornata.

Roxburgh $(1814,1824,1832)$ clearly intended the name $L$. ornata to apply to a plant from $\mathrm{N}$ India. Despite slight inconsistencies in his description as published 
(Roxburgh, 1824, 1832), it is equally clear that he intended the name to apply to a shrub which, if it twined at all, only did so occasionally at the ultimate branches. Roxburgh's plant was not a vigorous climber although many later authors, beginning with Wight (1848), have misapplied the name to such a plant.

The Roxburgh drawing at $\mathrm{K}$ corresponding to his manuscript description is numbered 1535 and labelled Ipomoea ornata (Sealy, 1957: 354). This combination has never been validly published. Roxburgh (or possibly Carey when editing Roxburgh's manuscript for publication) clearly changed his mind as the species was eventually published as Lettsomia ornata Roxb. Sealy (1957) stated that Roxburgh's drawings were numbered consecutively according to his Flora Indica manuscript and sent to Kew at intervals from 1796 onwards; no. 1463 was sent between 1803 and 1804 (Sealy, op. cit. 300). Hence it follows that no. 1535 l. ornata dates from around 1803, or later, i.e. about a year after Hardwicke's living material was introduced to Calcutta Botanic Garden. From this, it also follows that Roxburgh's unpublished manuscript description of the species dates from around 1803, as he prepared his descriptions and illustrations more or less simultaneously.

Wallich (in Roxburgh, 1824: 86) added a footnote stating that he had found L. ornata in various parts of Nepal, mainly near Kathmandu, in the thick forest at Hetounra [Hataura] and along the tortuous tract of the Rapti; also ... at the foot of Mount Nag-Urjoon [Nagarjung] and Shivapoora [Sheopore]'. Most of these appear to be field records; only a single gathering representing them, Wallich 1369:1 localized 'Hetaunra', has been traced (K-W; G-DC, microfiche seen). In his footnote. Wallich mentioned a climbing, twining habit, and indicated that the plant was synonymous with what he called 'Convolvulus candicans Roth'. The K-W example of Wallich 1369/1, labelled 'Lettsomia ornata Roxb. Legi ad Hetounra Decemb. 1820', has been examined. It (and the G-DC example) agrees exactly with the description given in Wallich's footnote. Wallich's specimens are mature fruiting plants; they do not exactly match the plant cultivated from Hardwicke's introduction (Wallich $1369 / 2$ ) although they appear to be conspecific and were so treated by Prain (1894). However, Wallich 1369/1 was collected in 1820, many years after Roxburgh prepared his manuscript description and also several years after Roxburgh's death in 1815 . Hence, Wallich 1369/1 cannot represent type material of $L$. ornata Roxb.

Clarke (1883: 183) seems to have doubted whether Roxburgh's L. ornata was native to $\mathrm{N}$ India, for he wrote, 'Roxburgh says he obtained seeds of this from Cawnpore (possibly from a garden?); no examples have been seen from the South Deccan'. Roxburgh ( 1824 ) made no mention of garden origin for Hardwicke's collection, so Clarke could not have known if the plant had come from a garden (rather than being subsequently planted at Calcutta). Garden origin of Hardwicke's plants of $L$. ornata is here considered unlikely; Hardwicke was an enthusiastic naturalist and made many botanical drawings 'on the spot' in the field (Britten, 1906). Without definite information, it is impossible to discount the possibility of garden origin. although Prain (1896) records that plants identical to Roxburgh's original concept of $L$. ornata were subsequently collected over a wide area of the sub-Himalayan tract. 


\section{Convolvulus candicans Roth}

The nomenclature and typification of $C$. candicans Roth ex Roem. \& Schult. is summarized above. Benjamin Heyne, a German Moravian missionary, went to Tranquebar in 1792 and was superintendent of the Bangalore Gardens from 18021808 (Stafleu \& Cowan, 1979). Tranquebar (Tarangambudi, Tamil Nadu) and Bangalore (southeastern Karnataka) are both in the southern Deccan; most, if not all, of Heyne's collections were made in this region, rather than in $\mathrm{N}$ India where Hardwicke's plants of $L$. omata had been collected. All the sheets labelled $C$. candicans in $\mathrm{K}-\mathrm{W}$ belong to $R$. hypocrateriformis. There appear to be none of $C$. candicans Roth ex Roem. \& Schult. in B-Willd; all the sheets there (B-Will. 3692), and the specimen in LINN-Smith (307.16), belong to C. candicans Willd. ex Roem. \& Schult. and represent type material of that taxon $(=R$. hypocrateriformis). $C$. candicans $\mathrm{Roth}$ ex Roem. \& Schult. is doubtless the source of the 'Coromandel' records of $R$. ornata cited by Don (1838) and Voigt (1845).

\section{Subsequent widening of the application of $\mathrm{R}$. ornata (Roxb.) Choisy}

It has been established above that the origin of Hardwicke's plants that served as the basis for the type collection of L. ornata was Uttar Pradesh and that the plant had a shrubby, virtually non-twining habit. However, the name has been frequently misapplied to a different, strongly climbing plant from the Deccan and Sri Lanka. Some of this confusion can be attributed to Wallich's editorial footnote to Roxburgh's description, which mentioned $C$. candicans Roth [ex Roem. \& Schult. 1819: 273 \& 790]. Roth did not describe his $C$. candicans as climbing or twining (fruticosus ... caule erectiusculus ...), but C. candicans Willd. ex Roem. \& Schult. (1819: 302, published simultaneously with $C$. candicans Roth ex Roem. \& Schult.), was described as a twiner ('caule volubili'). Later authors no doubt confused the two taxa and in so doing attributed a climbing or twining habit to $C$. candicans Roth ex Roem. \& Schult. and thus to R. ornata (Roxb.) Choisy with which it was generally synonymized.

Choisy (1833), when transferring Roxburgh's L. ornata to Rivea, was the first to enlarge its limits. As well as Lettsomia ornata Roxb., Convolvulus ornatus Roxb. [correctly (Roxb.) Wall.] and Argyreia ornata [Roxb.] Sweet, he included two other elements: Convolvulus candicans Roth, and herb. Wallich 2253, named Convolvulus tarita. C ornatus sensu Choisy embraced both Wallich 1369/2 (type of L. ornata Roxb.) and Wallich 1369/1 (Nepal) as both are in G-DC. C. tarita belongs to R. hlpocrateriformis, as discussed below; hence it must be excluded from any concept of $R$. ornata. Choisy appears to have been influenced when drawing up his description by Roth's $C$. candicans (and Wallich's footnote saying that the latter was supposedly the same as $R$. ornata). His transfer of L. ornata Roxb. to Rivea, together with the other included elements, created a confused taxon. in effect 'R. ornata sensu Choisy non L. ornata Roxb.'. 
$R$. ornata sensu Choisy, including plants from both north and south India, has been similarly treated by the following authors among others: Don (1838: 254): Voigt (1845: 351); Drury (1866: 295); Woodrow (1898: 170); Vickery in Hara et al. (1982: 108): Naithani (1985: 448); Haridasan \& Rao (1987: 645). Drury (loc. cit.) stated that the plant was a climber; thus, the Deccan plant formed the basis of his species concept. Woodrow's concept is not known as his 1898 checklist lacked descriptions, but he was dealing with the flora of western India mainly around Mahabaleshwar and thus the plant known to him would have been the Deccan taxon; however he followed Clarke's nomenclature (1883) in its inclusive sense. Naithani (1985: 448) described $R$. ornata as a 'climbing shrub'; his description is otherwise too brief and inadequate to identify the taxon he was dealing with, but his work was concerned with an area at the western end of the sub-Himalayan tract and thus he would have been dealing with $R$. ornata in the sense Roxburgh used the basionym.

\section{Convolvulus tarita Buch.-Ham.}

Convolvulus tarita Buch.-Ham. ex Wall., Numer. List 67, no. 2253 (1830), is a nomen nudum. Prain (1894: 89) remarked that there was no material of its 'type', BuchanamHamilton in herb. Wallich 2253, at Calcutta. The specimen which should be in K-W under this Wallich number is also missing (IDC undated; confirmed by present author. 1992). There is at $\mathrm{E}$ a specimen, originally presented to the University of Edinburgh in 1830 with Buchanan-Hamilton's herbarium, which bears two labels. Of these, the lower is one of Francis (Buchanan) Hamilton's partly printed labels (the handwriting is probably that of an amanuensis), numbered 515, with the name 'Convolvulus Tarita', and 'Tarita Sanscritar. Habitat in Magadhar dumetis'; the other. immediately above and entirely handwritten, reads 'Convolvulus Tarita. Mongger 10th Sept. 1811'. Thus, this specimen is virtually certain to be original material of C. tarita. The 'Magadhar' label agrees with entry no. 515 in Hamilton's catalogue (Hamilton, 1830) which gives additional information ('Brihat Tarachandi officinarum Hindice') but does not mention a collection from Mongger. Another specimen (G-DC, microfiche seen; labelled 'Mongger 10 th Sept. 1811') is obviously a duplicate but apart from the identical handwriting, locality and date there is nothing to link it with Buchanan-Hamilton. It is conspecific with the E specimen. Buch-Ham. 515 (E) has been compared with the two syntypes of $R$. omata var. griffithii C.B. Clarke and other material definitely referable to that taxon, and with material of $R$. hypocrateriformis. All plants of var. griffithii have flowering calyces c. $14 \mathrm{~mm}$ long; those of R. hypocrateriformis are $8-10 \mathrm{~mm}$ long. There are also subtle, less constant differences in the shape of the leaf base; $R$. omata var. griffithii most commonly has a very broadly and shallowly cordate leat base, that of $R$. hipocrateriformis is more narrowly and more deeply cordate. Buch-Ham. 515 has leaves of the latter type and flowering calyces $910 \mathrm{~mm}$ long. It is concluded. therefore. that comblvalus tarita is synonymous. not with $R$. ornata. but with $R$. hipoctatertomis. This confirms Prain's 
suspicion, based on his field knowledge, that only one Rivea, R. hypocrateriformis, grew in Bihar (Prain, 1894: 88-89). As a nomen nudum which has never been validated, the transfer of this synonym from $R$. onnata to $R$. hypocrateriformis has no nomenclatural significance, but it is important as $C$. tarita clearly formed the basis of the 'Monghir' records of $R$. ornata in Choisy (1833, 1845). Don (1838) and Voigt (1845).

\section{Definite misapplication of $\mathrm{R}$. ornata to $S$ Indian plants}

Wight's account of $R$. ornata (Wight, 1848 ) very clearly refers to the Deccan plant because he stated 'stems climbing'. Indeed, the only specimen he cited was from 'Balaghaut mountains. Madras'. This almost certainly refers to the hills in the Cuddapah district NW of Madras (formerly called Balaghaut), rather than the Palghat district of Kerala or the Balaghaut Range in Maharashtra; the only Rivea known from either of these latter areas is $R$. hypocrateriformis, not $R$. ornata or the southern taxon confused with it (cf. Vajravelu, 1990) whereas the southern ' $R$. omata' has frequently been collected from the Cuddapah area (see citations below, under R. wightiana R.R. Mill). The accompanying illustration, t. 1356, is not one of the c.400 in Wight's work that were copied from Roxburgh's drawings; it may well have been made from the Balaghaut specimen. An unlocalized specimen ( $K$ ) is a very close match to the illustration but is not identical to the plant drawn; it may be a duplicate of the same gathering as was used to prepare the drawing. Wight's work apparently represents the first definite (mis)application of the name $R$. ornata to plants from southern India and probably represents the principal source of all the later confusion, caused by other workers copying him. A list of works using the name in this incorrect sense is given above under $R$. ornata auct. non (Roxb.) Choisy.

\section{Discrimination of taxa within $\mathrm{R}$. ornata}

Clarke (1883: 183) for the first time discriminated two taxa within Rivea ornata. Possibly because Wight had previously done so, Clarke unfortunately attached the name Rivea ornata (Roxb.) Choisy (including its basionym, Lettsomia ornata Roxb.) to the southern taxon. From this, which he (like Wight) appeared to regard as 'typical $R$. ornati, he separated the northern taxon as var. griffithii C. B. Clarke. Clarke's action means that, under the current ICBN (Greuter et al., 1994), the southern plants should. in theory, be given the autonym $R$. ornata var. ornata whenever varietal rank is awarded to them. However. the type of the basionym, and thus of $R$. ornata var. ornata, is that made from the living plants Hardwicke had collected in the vicinity of Cawnpore.

Prain (1894: 88 89) clarified matters biving a full nomenclatural treament of both taxa recognized by Clarke. Prain reicred to the southern one as Rivea mata Choisy var. typica Clarke [sic]. excluding the synonyms of Roxburgh. Wallich. Buchanan-Hamilton. Sweet and Brandis we included the basionym of 1 . omatit. 
Var. typica, whose epithet should be attributed to Prain as Clarke did not explicitly publish it, was equated with Convolvulus candicans Roth ex Roem. \& Schult. (1819: 273 \& 790; non C. candicans Willd. ex Roem. \& Schult. 1819: 302). Prain confirmed Clarke's distributional statement (1883: 183) by stating that $R$. ornata var. typica appeared to be 'strictly confined to South India and Ceylon'. The northern plant. var. griffithii C.B. Clarke, in whose synonymy Prain included Lettsomia ornata Roxb. and Argyreia ornata (Roxb.) Sweet. was cited from several localities in the subHimalayan region 'from the Sivaliks to the Sikkim Terai'.

Prain, as he made abundantly clear in his footnote (op. cit. 88-89), had finally realized that the northern and southern plants were not only probably specifically distinct, but that the application of the specific epithet ornata had been confused. He writes, '... the plant figured by Roxburgh in his Ic. Ined., and described by him. is not the South Indian but the sub-Himalayan plant. It is to the latter that Roxburgh's trivial name of 'ornata' ought therefore rightly to belong; but as its application to Roth's Convolvulus candicans has now become stereotyped, it will be necessary to allow the name Rivea ornata Choisy, to continue to designate the plant from Southern India, and be preferable to name the North-Indian one Rivea Roxburghii ...' Shortly afterwards (Prain, 1896: 537), he noted that H. Haines had brought 'further large suites of this very distinct variety [ $R$. omata var. griffithii] from the Duars ... These make it more probable than ever that Roxburgh's plant is specifically distinct from Convolvulus candicans Roth". He stated that Haines had found it growing 'at least as far as the Assam frontier', and that King's collectors had brought back large quantities of the same taxon from the Southern Shan States (Myanmar). He noted that, "From no part of its wide area, (from the Sivaliks to the Shan Hills) come any specimens showing the slightest tendency to connect Roxburgh's plant with Roth's one from Southern India'.

Prain's publication (1894: 89) of the name Rivea roxburghii does not constitute valid publication under Art. 34.1 of the current ICBN (Greuter et al., 1994), since it was merely a provisional name given in the future tense: it has never appeared in Index Kewensis. His taxonomic conclusions and circumscription of the taxa are. nevertheless, correct. The name $R$. roxburghii Prain was validated in Brandis (1906: 484 ) by a short English description, together with a reference back to Prain's first mention of the name, which should be cited (and added to Index Kewensis) as $R$. roxburghii Prain ex Brandis. Although not formally typified, it was an avowed nomen novum for Lettsomia ornata Roxb. and thus should also be typified by Wallich 1369/2. Hence $R$. roxburghii is also a taxonomic synonym of that part of $R$. ornata (Roxb.) Choisy which includes the basionym, but it is not synonymous with $R$. ornata in its misapplied sense.

Nevertheless, for the past century, Prain's conclusions appear to have been overlooked. Nearly all standard Indian regional Floras have continued to uncritically follow Flora of British India and either misapply Rivea ornata to the southern taxon (e.g. Watt, 1892: 558; Trimen, 1895: 205-6; Cooke, 1908: 254; Gamble, 1922: 904: Henry et al., 1987: 111; Singh, 1988: 452) or else treat the name in a broad sense 
encompassing both northern and southern plants (e.g. Vickery in Hara et al., 1982: 108: Haridasan \& Rao, 1987: 645). The northern taxon, when separately distinguished. is normally called $R$. ornata var. griffithii C.B. Clarke, e.g. Prain (1903: 739 ); Haines (1922: 585); Gupta (1928: 342-3); Kanjilal et al. (1939, 3: 340); Deva \& Jain (1979: 269-272).

Raizada (1976) decided that the Rivea occurring in the Dehra Dun area was not the same as $R$. ornata (Roxb.) Choisy and referred it to $R$. laotica Ooststr., described from Laos by van Ooststroom (1957). Raizada was correct in discriminating two taxa, but it appears that by $R$. ornata (Roxb.) Choisy he actually meant the southern plant ( $R$. ornata auct. non (Roxb.) Choisy). His treatment was followed by Babu (1977). However, Deva \& Jain (1979). in a critical investigation based partly on fresh. field-collected material and partly on available specimens, regarded the Dehra Dun Rivea as $R$. omata var. griffithii. They considered that $R$. laotica was synonymous with $R$. ornata var. gifffithii, and simply the latter taxon at the easternmost limit of its range. If their conclusions are correct, which is quite likely given that Prain cited collections of $R$. ornata from the Shan States (Myanmar), the correct name at species rank for $R$. laotica is $R$. omata (Roxb.) Choisy, or, if $R$. omata were to be conserved with a new type to preserve historic usage. $R$. roxburghii Prain ex Brandis.

\section{Lectorypification of $\mathrm{R}$. omata lat griffithii}

Clarke evidently saw thre specimens (syntypes) that he referred to his new variety: wo from Griftith's Herbarium (one 'from the Calcutta Botanic Garden, the other supposedly collected by (irilfith in Sikkim, where he never actually went). and the third collected by Falconer. In the type cover at $\mathrm{K}$ there are only two sheets: Falconer's, and Griffith H.E.I.C. 5854 ('Sikkim'). The origin of H.E.I.C. 5854 may have been Bhutan where Griffith did collect. but no specimen with a journal ticket has been found to confirm this. The third syntype. lowated by the present author at $\mathrm{K}$ in 1992, is simply labelled Rivea ornata H.B.C. ex Hb. Griffith'. Prain (1894: 88. fn.) wrote. "The specimens in Griffith's Herbarium are from the Roxburghian plants of the Calcutta Botanic Garden'. The third syntype. with that origin stated, is very likely also an isotype of Lettsomia ornata Roxb. or at least a 'clonotype' of it (i.e. a specimen taken at a later date than the original type specimen. but from the same living accession at Calcutta). All three sheets bear Clarke's handwritten determination, 'Rivea ornata var. griffithii'. The Grifith specimens are in fruit, while the Falconer one bears three short flowering stems (with buds but no fully open flowers) and two separate leaves. Clarke separated his variety principally on the basis of peduncle length (' $1-4 \frac{1}{2}$ in.', as opposed to " $1 /$ in or less' in his concept of 'typicat $R$. ornata'), leaves less silky beneath and corolla imb "glabrous without even in the bud". The last character could only have come from the Falconer specimen, as the Griffith ones have no flowers. The peduncles on the Falconer sheet are 1.5-4.5 incles $(45-110 \mathrm{~mm})$ long: on both Griffith sheses the triting peduncles are about 1.2 
inches $(20-50 \mathrm{~mm})$ long. Although Clarke named the variety after Griffith, this should not necessarily be used as a reason to favour one specimen over the other in choosing a lectotype. Since the Falconer sheet is a closer match in peduncle length to Clarke's measurements, and also the only one showing the diagnostic glabrous corolla exterior, it, and not either of the Griffith specimens, is here selected as the lectotype of Rivea ornata var. griffithii. Prain (1894: 88) stated that Falconer's specimen was collected in the Sivaliks.

Prain transferred Lettsomia ornata Roxb. and Argyreia ornata (Roxb.) Sweet from the synonymy of his $R$. ornata var. typica to the synonymy of var. griffithii. Thus. from 1894 var. griffithii became a taxonomic synonym of Roxburgh's Lettsomia ornata and hence of $R$. ornata (and of $R$. roxburghii Prain ex Brandis).

\section{Nomenclatural consequences}

Taxonomically, R. ornata var. griffithii C.B. Clarke (lectotype, Falconer s.n.. K) is identical to Lettsomia ornata Roxb. (type, Roxb. in Wallich 1369/2, K-W). Thus. if the northern and southern taxa are regarded as varieties of one species, it is the northern one that should be called var. ornata (syn. var. griffithii). General usage on the other hand has been to call the southe'n one 'var. typica' or simply $R$. ornata, and to incorrectly include the type of the basionym in the concept of the southern taxon.

There are three possible options open to resolve the nomenclature. These have different consequences but all upset historic usage to a greater or lesser degree. They are:

1. Strictly follow Art. 10.4 and retain the existing nomenclatural type of Lettsomia omata. Wallich 1369/2, without rejection of the name as allowed for by Art. 56.1. Nomenclatural consequences: Northern taxon remains $R$. ornata (Roxb.) Choisy at species rank (syn. R. roxhurghii Prain ex Brandis); at varietal rank, becomes $R$. ornata var. ornata (syn. $R$. ornata var. griffithii C.B. Clarke). Southern taxon, as a species, requires a nomen novum (typified by the type of Convolvulus candicans Roth ex Roem. \& Schult.) or else description as a new species, with new type; as a variety. it needs description as a new variety of $R$. ornata (Roxb.) Choisy.

2. Reject Le'tsomia ornata Roxb. under Art. 56.1. Nomenclatural consequences: Northern taxon at specific rank becomes $R$. roxburghii Prain ex Brandis (next available valid name): as a variety of the southern taxon, both a new specific epithet for the latter and a new varietal combination would be required. Southern taxon at species rank requires either a nomen norum (typified as under option 1) or a description as a species nova with a new type; at varietal rank it would have to be described as a new variety of $R$. roxhurghii.

3. Conserve the name Rivea ornata under Art. 14.1 with a new, conserved type (different to Wallich 1369/2), chosen from S Indian material, to preserve historic usage as much as possible. (This option has the same effect as the action recommended by Prain, 1894: 88.) Nomenclatural consequences: Northern taxon at species rank cannot be called $R$. ornata (Roxb.) Choisy as Roxburgh's type is now excluded. For the same reason, $R$ r roxburghii Prain ex Brandis also cannot be used, unless it too is conserved with a new type. As variety, becomes $R$. ormata 
Choisy var. griffithii C.B. Clarke. Southern taxon: because Roxburgh's type is excluded. the citation $R$. ornata (Roxb.) Choisy becomes incorrect. The combination is treated as dating from Choisy (1833), to be cited as $R$. ornata Choisy. Austin"s presently incorrect typification of $R$. omata remains incorrect, being superseded by the new conserved type. As a variety, the southern taxon becomes $R$. ornata Choisy var. ornata.

It is debatable whether $R$. ornata has been sufficiently 'persistently misapplied' for a formal conservation or rejection proposal to succeed, although one or other might help to stabilize the nomenclature. Usage has varied according to author, some restricting it to the type taxon, others widening it to include the non-type $S$ Indian taxon as well as the type taxon, others again misapplying it to the non-type taxon (see lists of usages under each name above). R. K. Brummitt (pers. comm., 1992), after reading an early draft of this paper, considered that there seemed to be a case for making a proposal under what was then Art. 69, but that it would probably be rejected because the epithet ornata had on occasion been used in a broad sense including both northern and southern taxa. Another reviewer of a later version of the paper suggested that an Art. 14 proposal to conserve the name with a new type should be considered in order to maintain historic usage.

Article 57 requires that a name that has been widely and persistently used for a taxon or taxa not including its type is not to be used in a sense that conflicts with current usage unless and until a proposal to deal with it under either Art. 14.1 or 56.1 has been submitted and rejected'. As I consider that (a) specific rank is appropriate for both taxa and (b) the name $R$. ornata has been used sufficiently often to denote either the northern taxon only or both it and the southern taxon, as an interim measure in this paper I shall use $R$. ornata for the taxon containing the historically accepted nomenclatural type of Lettsomia ornata Roxb. The southern taxon requires a new name. Although it has often been referred to by the illegitimate name Convolvulus candicans Roth ex Roem. \& Schult., the epithet candicans is not chosen here for use in Rive in spite of its descriptive aptness (the stems of the southern plant are often much more densely white-tomentose than in $R$. ornata from $N$ India). I consider that to continue usage of candicans would create further confusion as the epithet has been used in closely allied genera (e.g. Ipomoea) to denote other taxa (and also in the totally unrelated but nomenclaturally very confusable Theaceous plant, Lettsomia candicans (Tul.) Choisy, now classified in the genus Fre-iera Willd.). Instead, the epithet wightiana has been chosen, since it was Robert Wight who first definitely misapplied the name $R$. ornata to the Deccan plant. A proposal to conserve $R$. ornata with a new type under Art. 14.1 will be submitted for consideration by the Spermatophyta Committee. If this is eventually accepted, $R$. wightiana R.R. Mill (the southern taxon) will revert to $R$. ornata Choisy while $R$. ornata (Roxb.) Choisy in the present account will become $R$. roxburghii Prain ex Brandis.

Key to species

1a. Sepals c. $8 \mathrm{~mm}$, obtuse

R. hypocrateriformis

1b. Sepals 11-16mm, acute, subacute or obtuse 
2a. Erect shrub, very rarely with ultimate branches twining: petioles appressedpubescent; bracteoles $5-9 \mathrm{~mm}$; mid-petaline bands of corolla totally glabrous except for extremely sparse marginal hairs in uppermost $1 / 3$

R. ornata

2b. Vigorous twiner or climber; petioles densely white-tomentose; bracteoles usually $10-13 \mathrm{~mm}$, sometimes longer; mid-petaline bands of corolla usually \pm densely pubescent throughout their length (occasionally subglabrous)

R. wightiana

Rivea ornata (Roxb.) Choisy. Convolv. Or. 27. t. 3 (1833) and in A.DC.. Prodr. 9: 326 (1845). For typification of this and all synonyms see Introduction.

Basionym: Lettsomia ornata Roxb., Hort. Bengal 13 (1814) nom. mad.: Roxb.. H1. Ind. ed. Carey \& Wall. 2: 86 (1824) \& ed. Carey l: 496 (1832).

Syn.: R. ornata (Roxb.) Choisy var. griffithii C.B. Clarke in Hook.f.. H1. Brit. India 4: 183 (1883).

R. roxburghii Prain ex Brandis, Indian Trees 484 (1906).

$R$. laotica sensu Raizada et auct. ind. plur. ? etiam Ooststr. in Blumea 8: 525 ( 1957 ).

Erect shrub, the ultimate branches finally scandent or twining but not vigorously. Branches hollow, appressed-pubescent, flexuous. Petioles $35-125 \mathrm{~mm}$. densely appressed-pubescent: lamina ovate-suborbicular to broadly ovate. $50120 x$ $55-170 \mathrm{~mm}$, base shallowly to moderately cordate, apex obtuse or shortly and abruptly acute; upper surface minutely puberulent, lower surface grey-pilose (but lamina surface visible), hairs c. $0.7 \mathrm{~mm}$, somewhat crispate: margin densely white- or pale yellowish-villous. Cimes 2- or 3-flowered. Peduncles $2080 \mathrm{~mm}$ in flower. $30-150 \mathrm{~mm}$ in fruit, appressed-pubescent. Pedicels $5-10 \mathrm{~mm}$ in flower. $1220 \mathrm{~mm}$ in fruit, gradually broadened below calyx. Bracteoles linear. $59 \mathrm{~mm}$, acute. pubescent. Calyx: outer lobes oblong, $14-16 \times 5.5-6 \mathrm{~mm}$, obtuse, appressed-pubescent outside. margins less so; inner lobes oblong-elliptic. obiuse (but innermost lobe emarginate). appressed-pubescent but with glabrous margins. Corolla white. fritgrant opening at night and withering by next morning; tube c.50mm long, 4-5mm broad near batse. gradually dilated and c.6.5mm broad below limb; limb $25.30 \mathrm{~mm}$, c.50mm diam.. mid-petaline bands totally glabrous except for exceedingly sparse marginal hairs in upper 1/3. Fruit globose or subglobose, 15--20×15-20mm. chestuut brown to dark brown; calyx lobes remaining erect at fruiting stage.

Distribution. India (sub-Himalayan tract of N India from Jumna eastwards: common in Jalpaiguri duars. Darjeeling ete.), extending through Nepal and Assam to S Shan States (Myanmar); ?Thailand and Laos [if $R$. laotica Ooststr. is conspecific]. Sal forest and terai; $250-600 \mathrm{~m}$.

Representative specimens examined. INDIA. Bihar: Chota Nagpore. Hetghat. Jashpur. 1500-2000ft, 29 xi 1896. J.J. Wood 139 ( K). Nag Pahar forest, near Lailunga. Ratigarh. under moderate shade on gritty soil from granite gneiss. $1700 \mathrm{ft}, 3$ ii 1936 . vernacular names $P /$ cuink 
(Chhattisgarhi) and Chunoti (Uraan), Mooney 307 (K): Siwaliks. Saharanpur, i 1893. Gumble 24040 (K): H.B.C. [Botanic Garden. Calcutta]. ex Hb. Griffith (K. possibly isotype or 'clonotype' material of $L$. omatu Roxb.). Tookria Jhar. 8 xii 1875. Gamble 317C (K): Pashok. 3000ft. 25 viii 1876. Gamble 939 (K). Darjeeling terai, Scoike(?) Sal Inat(?). vii 1874. Gamble 3402B (K); Darjeeling. Jhenaikuri. xii 1879. Gamble 7599 (K).

VEPAL. Far West: Mahakali Zone. Kanchapur district, 25 miles NW of Dhangarhi. sal forest. 250m. 7 xii 1966. D. H. Nicolson 2855 (BM: approaching $R$. hypoctuteriformis). C Nepal. Hitaura, Rapti valley, $2725^{\prime} \mathrm{N} 8505^{\prime} \mathrm{E}, 1500 \mathrm{ft}$, in sal forest, 22 viii 1967 . Williams \& Stainom 8204 (BM. K; originally named $R$. hipocrateriformis, BM specimen redetermined by Vickery as $R$. ornata: from same locality as Wallich $1369 / 1$ ).

\section{Rivea wightiana R.R. Mill. sp. nov.}

Гуре: The illustration of Rived onnata in Wight. Ic. Pl. Ind. Orient. 4: t. 1356 (1848) Epitype (designated here): India. unlocalized, Wight s.n. ( $\mathrm{K}$ ): possibly from same gathering as was used to draw the illustration.

Syn.: Convolvulus andicans Roth ex Roem. \& Schult., Syst. Veg. 4:273\& 790(1819) nom. illegit. non C. candicans Sol. ex Sins in Bot. Mag. t. 1603 (1813). nec $C$. rmaticans Willd. ex Roem. \& Schult.. op. cil. 302 (1819). Type: 'in India orientali". b. Home (?K).

[R. ornata auet, mult. non Le'tsomia ornata Roxb.]

I R. mallo vero (plantat Roxburghiana) differt habitu volubili vel scandenti. conis medianis petalorum saepissme omnino pubescentibus usque albidosericeis pedunculis multo brevioribus $(10-20 \mathrm{~mm}$. non $20-80 \mathrm{~mm}$ tempo florendi in ructu usque i. 0 min accrescentibus).

Vigorous twiner or climber: branches \pm flexuous, 2 6mm thick. densely tomenose with short hairs mostly $0.10 .2 \mathrm{~mm}$. Petioles $2560 \mathrm{~mm}$, densely tomentose: lamina broadly ovate-reniform. $2570 \times 30105 \mathrm{~mm}$. base always distinctly though oometimes shallowly cordate. apex obtuse or less commonly very shortly acuminate. margin usually whitish: upper surfice rather densely brownish-puberulent coften appearing glabrous, but leaves rough to touch and sometimes with very few bhort hairs lower surface densely or very densely grey- or white-tomentose thairs 0.2 0.5mm). Cimes 3 9-flowered. aggregated, occasionally flowers solitary. Pedancles 10-20mm, densely tomentose. Pedicels c.5mm in flower. Bracteoles usually 10-1.3 mm (sometimes longer). Callix 12 16mm: outer lobes broadly oblong. acute or subacute, densely tomentose w ith no glabrous margin, inner ones glabrous except for pubescent mid-line. (orolla 70 $90 \mathrm{~mm}$; tube $35-55 \mathrm{~mm}$. pilose or sericevis in upper half. glabrous in lower hall: limb c. $25 \mathrm{~mm}$. With nid-petaline bands \pm densely pubescent throughout their length (rarely almost glabrous). Fuit ovoid or subglobose, c. $20 \times 15 \mathrm{~mm}$, redish-brown. calyx lobes erect in young fruit.

Dismihutom. SE \& SW Indiat. Sri Lanka. Little is known about its habitat ats few specinens bear details.

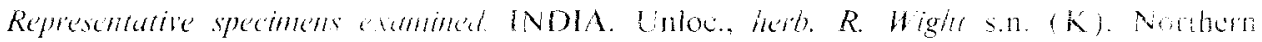
Dravidian, herh. H.F.C. Cleghorn (E), Maharashtra Karnataka/Kerala: Malabar. Cincan 
\&c., Stocks s.n. (K): unlocalized, Bombay herbarium of N.A. Dalzell ( K). Tamil Nadu: Madras, Nilgiris district, Masnigudi, 3000ft, xi 1886. Gamhle 18469 (K): Lower Pulneys. Machur, 1897, Baidhs(?), Sir A.G. \& Lad. Bourne 1629 (K). Karnataka: Maisor [Mysore] and Carnatic. G. Thomson (BM, K - mid-petaline bands, and corolla tube, tglabrous). Andhra Pradesh: Madras, 1912, Gamble (K); Cuddapah district. Cuddapah hills, Beddome 5513 (BM): Madras, Cuddapah district, Ghalloo, 2800ft, vii 1884, Gamble 15168 (K).

SRI LANKA [CEYLON]. Unlocalized, Thwaites C.P. 1946 (BM, K). 1.5 miles beyond Kalpitiya, very common in open thorn scrub with Borassus, extensive twiner covering shrubs and small trees, 14 xi 1970, Fosberg \& Jarasuria 52745 (E, K).

A specimen from the far south of India (Tamil Nadu: Coimbatore district, hillside near Coimbatore, climber, 5 iv 1937, J.W. Andrews A359, BM) may belong to $R$. wightiana but has leaves glabrous (though rough) on the upper surface and thinly short-pubescent beneath, with the lamina surface visible (as in $R$. ornata). Corollas are not present and hence a definite identification is difficult to make. It may instead be referable to $R$. hypocraterifomis.

\section{OTHER LECTOTYPIFICATIONS}

Argyreia hirsutissima (C.B. Clarke) Raizada in Ind. Forester 93: 754 (1967).

Basionym: Letsomia hirsutissima C.B. Clarke in Hook.f., Fl. Brit. India 4: 193 (1883).

Syn.: [Convolvulus hirsutissimus Wall., Numer. List 38, no. 1400. nom. mud. (1829).]

Argyreia capitata $\beta$ conferta Choisy in A.DC., Prodr. 9: 332 (1845).

Lectotype designated here (of Lettsomia hirsutissima and of $A$. capitata $\beta$ conferta): [Myanmar] Ad Taong-Dong, Wallich 1400 ( K-W. isolecto. BM).

Clarke's protologue of $L$. hirsutissima cited the original material thus: 'Sikkim Himalaya, alt. $5000 \mathrm{ft}$., Tendong, C.B.Clarke. - Distrib. Ava'. He listed two synonyms (see synonymy above). The Sikkim record was based on Clarke 9835A, collected at Mendong on $23 \times 1869$, the label of which bears a detailed description with drawings. He obviously made much use of the specimen when drawing up his description of $L$. hirsutissima. However, since he also cited the unpublished name Convolvulus hirsutissimus Wall. (and Choisy's variety conferta based on the same type, Wallich 1400) and had access to its type, I designate Wallich 1400 as lectotype of L. hirsutissima C.B. Clarke. Wallich visited Taong-Dong (in the hills of the River Mytinge, a tributary of the Ayeyarwady [Irrawaddy]) in 1826. Wallich 1400 is clearly the source of Clarke's remark on the external distribution, Ava being the old name for that region of Myanmar (Burma).

Argyreia sikkimensis (C.B. Clarke) Ooststr. in Blumea 7: 178 (1952).

Basionym: Lettsomia sikkimensis C.B. Clarke in Hook.f., Fl. Brit. India 4: 194 (1883). Syntypes as cited by Clarke: 'Sikkim: Pomong, alt. $3000 \mathrm{ft}$. . C. B. Clarke. Khasia Mts., Silhet and Cachar, H.f. \& T., Keenan.' - corresponding to the following nine syntypes: Pomong, Darjeeling, 2000ft, 23 viii 1869, Clarke 8808 ( K, 2 sheets. 
one with detailed annotations; BM ); Khasia, H.f. \& T. [J.D. Hooker \& T. Thomson] with label '2097. 12. Argyreia. Lachen Hills Churra' ( K, 2 sheets, one leg. Hooker, dated 16 viii 1850): Silhet \& Cachar, J.D. Hooker \& T. Thomson ( K); 'Sikkim terai', J.D. Hooker \& Thomson ( K ): above Chola, 4 ix 1850, J.D. Hooker \& Thomson ( K). Lectotype (designated here): the sheet of Clarke 8808 ( $\mathrm{K}$ ) from Pomong bearing the detailed description and drawings on its label.

\section{NEW RECORDS}

Calystegia hederacea Wall. in Roxb., Fl. Ind. 2: 94 (1824).

BHUTAN. Mongar district: near Lingmethang. $122 \mathrm{~km}$ from Tashigang, $1050 \mathrm{~m}$, weed on banks, extending into wheat field plots, flowers pink, 19 iii 1991, C. Parker 4911 (E, WRO); $\mathrm{nr}$ Lingmethang $(125 \mathrm{~km}$ from Tashigang), $900 \mathrm{~m}$, occasional weed of rice seedling nurseries and fallow rice terraces, flower $3 \mathrm{~cm}$ diameter, streaked pink below, and leaf shape different to 7243,14 vii 1992, C. Parker 7245 (E. WRO).

First records from Bhutan. Distributed from Nepal to China, where it is particularly frequent in Yunnan.

Convolvulus arvensis L., Sp. Pl. 153 (1753).

BHUTAN. Mongar district. Lingmethang, $750 \mathrm{~m}, 14 \mathrm{vi} 1992$, occasional weed in fodder grass plots. flowers pale pink $2 \mathrm{~cm}$ across. C. Parker 7243 (E, WRO).

First record from Bhutan of this widely distributed weed.

Dichondra repens J.R. \& G. Forst., Char. Gen. Pl. 40, t. 20 (1776) var. repens.

BHUTAN. Ha district: between Ha and Puduna, 2797m (9180ft), 25 vi 1971, trailing herb, local name (Hindi) Brahmi. Ramesh Bedi 290 (K).

The specimen was originally misnamed as Hydrocotyle javanica Thunb. (Umbelliferae). D. repens is a very distinctive member of Convolvulaceae, small and prostrate with reniform or cordate-orbicular leaves and very small axillary greenish or whitish flowers. It is widespread in the warmer regions of both hemispheres. There are numerous records from Yunnan (China) but this seems to be its first record from the eastern Himalayan region. It has not so far been recorded from Nepal or further west in the Himalaya. Nevertheless, it can be easily overlooked on account of its small size.

\section{ACKNOWLEDGEMENTS}

I wish to thank the Directors of the Herbaria at BM and $\mathrm{K}$ for the loan of specimens and for facilitating the study of other material. I am also very grateful to Dr R. K. 
Brummitt (Royal Botanic Gardens, Kew) for reading a draft of the portion of this paper dealing with the typification of Rivea ornata and making valuable comments. The comments of an anonymous referee have also been of great benefit.

\section{REFERENCES}

AUSTIN. D. F. (1980). Convolvulaceae. In: DASSANAYAKE, M. D. (ed.) A Rerised Handhosk to the Flora of Cellon. Vol. 1. pp. 288-363. New Delhi: Amerind Publishing Co. Pvt. Ltd.

BABU.C.R. (1977). Herhaceous flora of Dehra Dum. New Delhi: Publications and Information Directorate (CSIR).

BRANDIS. D. (1906). Indicu Trees. London: Constable.

BRITTEN, J. (1906). Hardwicke's botanical drawings. J. Bot. 44: 235 241.

CHOISY. J. D. (1833). Convolvulaceae orienuales nempe indicas. napaulense's.

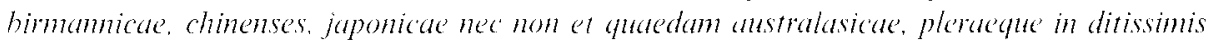

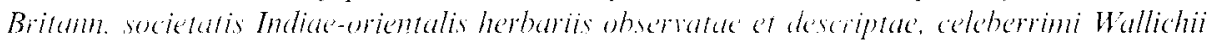
caldogo comparate, et sallica prastatione de generibus intra convolvulaceas admittendendis ionitalat. Genieve.

CHOISY. J. D (1845). Convolvulaceae. In: CANDOLLF. A. DE. Prodromes systematis inatuatis regni regetubilis. Vol. IX. Paris: Victor Masson.

C1.ARKE. C. 13. (1883), Convolvulaceate. In: HOOKER, J. D., Flora of Britivh India. Vol. 4, pp. 179- 228. London: L. Reeve \& Co. Ltd.

COOKE. T. (1908). The Flora of the Presidency of Bombay. Vol. II. Compositae to Gramineae. London: Taylor \& Francis.

DASSANAYAKE. M. D. (ed.) (1980), A Revised Handhook to the Flora of Ceylon. Vol 1. New Dethi: Amerind Publishing Co. Pvt. Ltd.

DAWSON. W. R (1946). On the History of Gray and Hardwicke"s I/lustrations of Indian Loologl, and sone biographical notes on General Hardwicke. J. Soc. Bihliogr. Not. Hist. (3): $55-69$.

DEVA. S. \& JAIN. S (1979). A note on the identification of Rivea (Convolvulaceae) from Dehra Dun. Indiun J. Forest. 2(3): 269272.

DON. G. (18.38). A Genest Histom of the Didhamedere Plants. Vol. 4(2). London: J. G. \& F Rivington et al.

DR URY H. (1866). Ifond-boek of the Indien Flort. Madras: Trabancore Sircar Press.

GAMBI.E. J. S. (1922). Flora of the Presidency of Madras. Vol. II. Rubiaceae to Fuphobiaceae. London: Adlard \& Co.

GREUTER. W. el a! (eds) (1994). Intemationat Code of Bonmical Nomendature

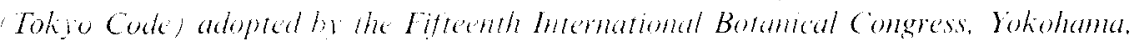
August September 1993. Reghtum lege 131.

GUPTA. B. L. (1928). Forest Flora of the Chakrata. Dehra Dum and Saharanpur Forest Givisums, Lnited Pronimes. Fd \& Calcutta. Government of India.

HAINES, H. H. (1910). A Fimes Flora of Chota Nagper ind luding Gangpar and the Santal-Paromahs. Calcuta: Covonment Printing.

HAINES. H H. (1922). The holamy of Bihat and Orised An acount of all the known

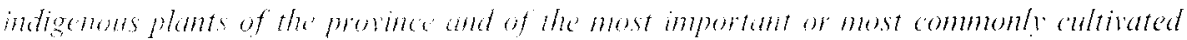

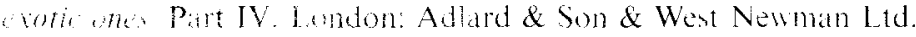

HAMILION, F. (BUCHANAN) (1830). A Culcilugle, warding to the Limnatem

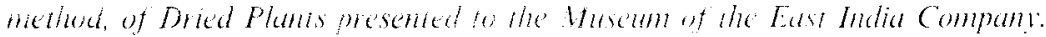

Unpublished handwanten malisucript. 
HARIDASAN. K.\& RAO. R. R. (1987). Forest flora of Meghalaya. Volume II. Caprifoliaceae to Salicaceae. Dehra Dun: Bishan Singh Mahendra Pal Singh.

HENRY. A. N.. KUMARI, G. R. \& CHITHRA, V. (1987). Flora of Tamil Nadu. India. Series I: Analysis. Coimbatore: Botanical Survey of India. Southern Circle.

HOOK ER. J. D. (1883 1885). The Flora of British India. London: L. Reeve \& Co. Vol. 4. (Convolvulaceae. pp. 179-228. by C. B. Clarke in 1883.) Reprinted. Dehra Dun. 1984.

IDC (undated). The Wallich Herharium the Herhatium of the East Indian Company) on microfiche. Zug: Inter Documentation Company AG. [17 microfiches with accompanying 36 pp leaflet, which includes a gazetteer.]

KANJILAL. U. N.. DAS. A.. KANJILAL, P. C. \& DE. R. N. (1939). Flora of Assam. Vol. III. Caprifoliaceac to Plantaginaceae. Government of Assam.

MANITZ. H. (1976). Zur Lectotypisierung der Namen einiger Convolvulaceen- und Cuscutaceen-Gattungen. Feddes Repert. 87: 311-317.

N AITHA NI. B. D. (1985). Flora of Chamoli. Vol. 2. Calcutta: Botanical Survey of India.

OOSTSTROOM. S. J. VAN (1957). Rivea laotica, a new species from Indo-China (Convolvulaceae). Blumea 8: $525-527$.

OSMASTON. A. E. (1927). A forest flora for Kumaon. United Provinces, Allahabad: Government Press.

PRAIN. D. (1894). Noviciae Indicae VIII. Some additional species of Convolvulaceae. J. Asiat. Soc. Bengal, Pt. 2. Nat. Hist. 63: 83-115. (Reprinted as Noviciae Indicate pp. 72-104, London. 1905.)

PRAIN, D. (1896). Noviciae Indicae XIII. Further notes on Indian Convolvulaceae. Ihid. 65: 536-538. (Reprinted as Noviciae Indicae pp. 174-176. London. 1905.)

PR A IN, D. (1903). Bengal Plants. A list of the phanerogams, ferns and fern-allies indigenous to, or commonly cultivated in, the Lower Provinces and Chitugong. Vol. II. Apocynaceae-Selaginellaceae. Calcutta.

RAIZADA, M. B. (1976). Supplement to Duthie's Flora of the Upper Gangetic Plain and of the adjacent Siralik and Sub-Himalayan tracts. Dehra Dun: Bishan Singh Mahendra $\mathrm{Pal}$ Singh.

RAO. M. R. (1914). Flowering Plants of Travancore. Trivandrum: Government Press.

ROEMER, J. J. \& SCHULTES. J. A. (1819). Caroli a Linné equitis Systema Legetabilium secundum classes ordines genera species. Cum characteribus, differentiis et sinonymiis. Editio nora. speciebus inde ab editione $X V$ detectis aucta et locupletata. Vol. IV. Stuttgardtiae: J. G. Cotta.

ROTH. A. W. (1821). Novac plantarum species praesertim Indiae orientalis. Halberstadii: H. Vogler. Facsimile ed. New York, 1975.

ROXBURGH, W. (1814). Hortus Bengalensis. Serampore, Calcutta: Mission Press.

ROXBURGH. W. (ed. W. Carey \& N. Wallich) (1824). Flora Indica; or descriptions of Indian plants. Vol. II. Serampore. Calcutta: Mission Press.

ROX BURGH. W. (ed. W. Carey). (1832). Flora Indica; or descriptions of Indian plants. Vol. II. Serampore. Calcutta: Mission Press.

SEA LY, J. R. (1957). The Roxburgh Flora Indica drawings at Kew. Kew Bull. 11: $297-399$.

SINGH. N. P. (1988). Flora of Eastern Karnataka. Vol. II. Delhi: Mittal Publications.

STAFLEU, F. A. \& COWAN, R. S. (1979). Taxonomic literature. A selective guide to botanical publications and collections with dates, commentaries and types. Ed. 2, 2. Regnum Ieg. 98.

STEWART. J. L. \& BRANDIS. D. (1874). The Forest Flora of North-llest and Central India. London: India Office. 
SWEET, R. (1818). Hortus suburbanus londinensis: or, a catalogue of plants cultivated in the neighbourhood of London, arranged according to the Linnean Sistem. London: James Ridgway.

SWEET, R. (1827). Hortus britannicus, or a catalogue of plants cultivated in the gardens of Great Britain. London: James Ridgway.

TR I MEN, H. (1895). A hand-book to the flora of Cellon containing descriptions of all the species of flowering plants indigenous to the island, and notes on their history distribution and uses. Part III. Valerianaceae-Balanophoraceae. London: Dulau \& Co.

VAJRAVELU. E. (1990). Flora of Palghat District including Silent Valley National Park. Calcutta: Botanical Survey of India.

VICKERY, A. R. (1982). Convolvulaceae. In: HARA, H., CHATER, A. O. \& WILliamS, L. H. J., An enumeration of the flowering plants of Nepal. Vol. 3. Trustees of British Museum (Natural History). London.

VOIGT, J. O. (1845). Hortus suburbanus calcuttensis. Calcutta: Bishop's College Press.

WALLICH, N. (1828-49). A numerical list of dried plants in the East India Company's museum. London.

WATT. G. (1892). A dictionary of the economic products of India. Vol. 6. Part 1 (Pachyriza to Rye). W. H. Allen \& Co., London \& Office of the Superintendent of Government Printing. Calcutta.

WIGHT, R. (1848). Icones plantarum Indiae ortentalis, or figures of Indian plants. Vol. IV. Madras: Franck.

WOODROW, G. M. (1898). The Flora of Western India. Part V. J. Bombal Nat. Hist. Soc. 12: 162-176.

Received 23 August 1995; accepted in revised form 26 Octoher 1995 